\title{
Post-embryonic developmentand lifetableparameters of Neoseiulus californicus on Tetranychus desertorum and Panonychus citri (Acari: Phytoseiidae, Tetranychidae) under laboratory conditions
}

\author{
Desarrollo post-embrional y parámetros de tabla de vida de Neoseiulus californicus sobre \\ Tetranychus desertorum and Panonychus citri (Acari: Phytoseiidae, Tetranychidae) bajo \\ condiciones de laboratorio
}

\author{
Víctor Tello Mercado ${ }^{1, *}$, Eliana Rojas Loyola ${ }^{1}$, Tommy Rioja Soto ${ }^{1}$ \\ ${ }^{1}$ Facultad de Recursos Naturales Renovables, Universidad Arturo Prat, Avenida Arturo Prat 2120, Iquique, Chile. \\ *E-mail: vetello@unap.cl
}

\begin{abstract}
The postembryonic development, and life table parameters of the Neoseiulus californicus were studied under laboratory conditions in order to evaluate the potentiality of this depredator for feeding on two phytophages mites Tetranychus desertorum (desert spider mite) and Panonychus citri (red spider mite). Tetranychus desertorum and P. citri may be considered as optimal food for N. californicus, which obtained survival rates of $100 \%$, on them. The time of the postembryonic development was significantly different $(p<0.05)$ between both diets. The periods of ovoposition, postoviposition and longevity of the $N$. californicus were $17.17 ; 4.37$ and 22.53 days, respectively, fed with $T$. desertorum, and 14.84; 5.23 and 21.06 days, respectively, fed with $P$. citri. The demographic parameters of $N$. californicus obtained fed with $T$. desertorum and P. citri were: intrinsic rate of increase $\left(r_{m}\right)=0.269 \pm 0.004$ and $0.307 \pm 0.004$, mean generation time $(T)=12.847 \pm 0.185$ and $10.791 \pm 0.142$, net reproductive rate $(R o)=31.792 \pm 1.478$ and $27.352 \pm 1.187$, finite rate of increase $(\lambda)=1.309 \pm 0.006$ and $1.359 \pm 0.006$, respectively. The high values of $r_{m}$ and $\lambda$ registered for $N$. californicus under experimental conditions are indicators of control potential that this phytoseiid presented as a predator over these phytophages mites.
\end{abstract}

Keywords: biological control, oviposition, postembryonic development, survival.

\section{RESUMEN}

El desarrollo postembrionario y parámetros de tabla de vida de Neoseiulus californicus se estudiaron bajo condiciones de laboratorio para evaluar la potencialidad de este depredador para alimentarse sobre los ácaros fitófagos Tetranychus desertorum (arañita del desierto) y Panonychus citri (arañita roja de los cítricos). Tetranychus desertorum y P. citri pueden considerarse presas óptimas para N. californicus porque la tasa de supervivencia fue de un $100 \%$ con ambos alimentos. La duración del desarrollo postembrionario de $N$. californicus fue significativamente diferente $(P<0,05)$ entre las dos dietas. Los períodos de oviposición, post-oviposición y longevidad de N. californicus fueron 17,17; 4,37 y 22,53 días (alimentado con T. desertorum) y 14,84; 5,23 y 21,06 días (alimentado con P. citri). Los parámetros demográficos de N. californicus alimentado con T. desertorum y P. citri, fueron: tasa intrínseca de crecimiento $\left(r_{m}\right)=0,269 \pm 0,004$ y $0,307 \pm 0,004$, tiempo generacional $(T)=12,847 \pm 0,185$ y $10,791 \pm 0,142$, tasa neta reproductiva $(R o)=31,792 \pm 1,478$ y $27,352 \pm 1,187$, tasa finita de crecimiento $(\lambda)=$ $1,309 \pm 0,006$ y $1,359 \pm 0,006$, respectivamente. Los valores altos de $r_{m}$ y $\lambda$ registrados para $N$. californicus, bajo las condiciones experimentales, son indicadores del potencial de control que presentaría este fitoseído como depredador de estos ácaros fitófagos.

Palabras clave: control biológico, desarrollo postembrionario, oviposición, supervivencia. 


\section{INTRODUCTION}

Mites are the most important crop pests after insects (Tello et al. 2011). These small arachnids cause severe damage to many crops, especially at high population levels (Mirabal 2003). Tetranychus desertorum Banks is associated with more than 173 host plants, distributed in Argentina, Brazil, China, United States, Hawaii, Mexico and Venezuela, among other countries (Bolland et al. 1998). The citrus red mite, Panonychus citri (McGregor), is a major citrus pest with a worldwide distribution (Shen et al. 2016). In Chile, T. desertorum and P. citri are pests of economic importance (Tello et al. 2013; Ragusa et al. 2000). T. desertorum is distributed from the Arica y Parinacota Region to the La Araucanía Region. In the Tarapacá Region, its hosts include alfalfa (Medicago sativa L.), beans (Phaseolus vulgaris L.), watermelon (Citrullus lanatus Th.) and malabar gourd (Cucurbita ficifolia B.) (Klein \& Waterhouse 2000). Panonychus citri is distributed in Chile from the Arica and Parinacota Region to the General Libertador Bernardo O'Higgins Region. It is associated with citrus lemon (Citrus limon (L.) Burm.), tangerine (C. reticulata Blanco), orange [C. sinensis (L.) Osbeck.], Grapefruit (C. paradisi Macfad.) (Klein \& Waterhouse 2000).

Predatory mites of the Phytoseiidae family are considered important biological control agents and are currently essential elements in integrated pest management programs, having great relevance especially in the management of phytophagous mites and a wide range of agricultural pests (Çobanoğlu et al. 2018; Ghazi et al. 2016; De Moraes et al. 2004). Although there is abundant information in the world regarding its characteristics, systematics and geographical distribution, in Chile research has mainly focused on descriptions and distribution of species from the central and southern part of the country, being scarce knowledge about the biodiversity of phytoseiid mites, especially in northern Chile. Information on existing species in the Tarapacá Region has been provided by Ragusa (2000), Ragusa et al. (2000), Ragusa \& Vargas (2002), Ragusa (2003), Tello et al. (2011) and Peralta \& Tello (2019). Neoseiulus californicus (McGregor) [=Cydnodromus californicus (McGregor)] is an effective biological controller of red spider mites, other plague mites and small insects (Castagnoli \& Simoni 2003).

Neoseiulus californicus has a high tolerance for high temperatures. Gotoh et al. (2004) recorded a hatchability of $97.8 \%$ and a mortality of $14.4 \%$ at $35^{\circ} \mathrm{C}$ for this phytoside. At $34{ }^{\circ} \mathrm{C}, \mathrm{N}$. californicus presented a hatching of $97.1 \%$ and a survival to adulthood of $74.3 \%$ (El Taj \& Jung, 2012). Canlas et al. (2006) studied the developmental time (in days) of immature stages of $N$. californicus at five constant temperatures. The developmental time was shortest at $35^{\circ} \mathrm{C}$ with an average of 3.41 days for males and 3.78 days for females. Kim et al. (2012) indicate daily fecundity of $N$. californicus was greatest at $24^{\circ} \mathrm{C}$ (1.9 daily egg/female) and $36^{\circ} \mathrm{C}(1.8$ daily egg/female), without statistical difference between both temperatures.

The average annual maximum and minimum temperatures recorded in Pica are $35.4 \pm 0.3{ }^{\circ} \mathrm{C}$ and $6.00 \pm 1.1{ }^{\circ} \mathrm{C}$, respectively, and the average relative humidity is $37.0 \pm 3.1 \%$ (Source: Agromet, INIA Agrometereological Network , http:// agromet.inia.cl/estaciones.php\#estaciones).

The objective of this study was to evaluate the effect of two phytophagous mites ( $T$. desertorum and $P$. citri) on the biological parameters of $N$. californicus in laboratory conditions that mimic the climatic conditions of the Pica Oasis.

\section{MATERIALS AND METHODS}

TRIAL LOCATION

The bioassays were performed in the laboratories of the Huayquique Campus dependent on the Arturo Prat University, under experimental conditions of $30.90 \pm 0.01{ }^{\circ} \mathrm{C}$ temperature, $43.32 \pm 0.03 \%$ relative humidity $(\mathrm{RH})$ and 14 hours light (L) and 10 hours dark (D) photoperiod. These micro-environmental conditions tried to emulate those that normally occur in the desert of northern Chile, where high temperatures and low levels of relative humidity are normally recorded.

\section{BIOLOGICAL MATERIAL}

Neoseiulus californicus was collected at the Canchones Experimental Station $\left(20^{\circ} 26^{\prime} 40.18^{\prime \prime} \mathrm{S}\right.$; $\left.69^{\circ} 32^{\prime} 03.87^{\prime \prime} \mathrm{W}\right)$, on alfalfa (Medicago sativa L.). For reproduction, $12 \mathrm{~cm}$ diameter black plastic plates were used (Swirski et al. 1970), using T. cinnabarinus as food. Tetranychus desertorum was collected in alfalfa plants at the Canchones Experimental Station. Both mites were multiplied in bean plants (Phaseolus vulgaris L.), grown sequentially (planted every 7 days) in plastic flower pots. Panonychus citri was collected from Pica $\left(20^{\circ} 29^{\prime} 12.43^{\prime \prime} \mathrm{S} ; 69^{\circ} 19^{\prime} 33.92^{\prime \prime} \mathrm{W}\right)$ on C. sinensis. This mite was raised on grapefruit fruits (Citrus paradisi Macfad) in 7-day infestation sequences. The three species of mites were kept in breeding conditions at $25.97 \pm 0.36{ }^{\circ} \mathrm{C}, 60.17 \pm 1.14 \%$ $\mathrm{RH}$ and photoperiod of 14:10 h (L:D).

\section{Post Embryonic Development}

In these trials the potential for development from the egg-toadult state of $N$. californicus was determined, fed a mixed diet of different stages administered ad libitum of $T$. desertorum and P. citri separately. A 20 -hour-old egg was placed on a $4 \times 4$ 
$\mathrm{cm}$ diameter plate, observed daily, at the same time, until the adult was obtained. These eggs came from different females kept in breeding with approximately ten generations elapsed since the establishment of the breeding. The survival and duration of each of the developmental states of phytoseiids was evaluated. The trials had 30 (for P. citri) and 31 (for $T$. desertorum) repetitions, corresponding to each repetition one phytoseiid egg per plate. All observations were made with a stereoscopic magnifying glass Carl Zeiss Stemi SV 6 (Germany).

\section{LIFE TABLE PARAMETERS}

The methodology described by Birch (1948) and applied by Ragusa et al. (2000), Vargas et al. (2005) and Tello et al. (2009a, 2009b) was used for determining the life table parameters of $N$. californicus. These parameters were: the intrinsic rate of increase $\left(r_{m}\right)$, net reproductive rate (Ro), generation time (T) and the finite rate of increase $(\lambda)$. In each plate a couple of phytoseiids was arranged, registering the ovipostura every 24 hours until the death of the female. The dead males were replaced so that the female was constantly fertilized. In addition to oviposture, the survival of the females in the cohort, the survival of the juveniles and the proportion or sex ratio were determined. The trials had 31 repetitions for $P$. citri and 30 repetitions for $T$. desertorum, corresponding to each repetition one female phytoseiid per plate.

DESIGN AND STATISTICAL ANALYSIS

A completely randomized design was used for all experiments. Normality was evaluated through the Shapiro-Wilks test. The survival percentage was analyzed through the non-parametric Wilcoxon test (Mann-Whitney U, p < 0.05, Zar 2010). To compare the duration of the egg to adult cycle between males and females, the t-Student test was applied ( $p<0.05)$. For the life table, the survival rate $\left(I_{x}\right)$ was expressed as the number of individuals alive at a time $x$, while the fecundity rate at a specific age $\left(m_{x}\right)$ was calculated based on the number of female offspring produced from a female in a time $x$. The estimated population parameters were: 1 ) net reproductive rate $\left.\left(R_{0}\right), 2\right)$ generation time $\left.(T), 3\right)$ intrinsic rate of increase $\left(r_{m}\right)$, and 4 ) finite rate of increase $(\lambda)$, which were estimated at from the results of fecundity and survival of females. The life table parameters were calculated through the $\mathrm{R}$ statistical data analysis environment, version 3.5.1. (R Core Team 2018) using the life table computer program.r (Nunes-Maia et al. 2014). To make comparisons between the life table parameters of the phytoseiid fed with two species of tetraniquids, the standard deviation at a $95 \%$ confidence interval was estimated using the Jacknife statistical technique (Ansaloni et al. 2007). The biological parameters were subsequently compared through a t-Student test $(p<0.05)$.

\section{RESULTS}

SURVIVAL AND DURATION OF THE LIFE CYCLE OF N. CALIFORNICUS FED WITH DIFFERENT DIETS.

No significant differences were detected between the survival rates of the two diets $(W=914.50 ; p=0.3094)$. It is clearly observed that the two foods had a positive influence when they were supplied reaching a survival of $100 \%$, being able to be characterized as optimal foods for $N$. californicus.

The duration of the cycle from egg to adult of $N$. californicus was 6.39 (SD: $\pm 0.95 ; \mathrm{n}=31$ ) days fed with $T$. desertorum and $5.57( \pm 0.57 ; \mathrm{n}=30)$ days, fed with $P$. citri, with highly significant differences between both $(t=-4.02, f d=$ 53, $p<0.0001$ ). In Table 1, it is observed that there were no significant differences between the two diets at the level of duration time of protonymphs $(t=0.11, f d=59, p=0.9139)$ and deutonymphs $(t=-0.17, f d=59, p=0.8626)$. The mobile states of larvae and adults (males and females) showed significant differences when fed with $T$. desertorum and $P$. citri. In the case of $N$. californicus larvae, they lasted significantly longer when fed with $P$. citri $(t=4.71, f d=59, p<0.0001)$.

TABLE 1. Effect of food type (Tetranychus desertorum and Panonychus citri) on the duration of post-embryonic development of Neoseiulus californicus. / Efecto del tipo de alimento (Tetranychus desertorum y Panonychus citri) sobre la duración del desarrollo postembrionario de Neoseiulus californicus.

\begin{tabular}{|c|c|c|c|c|c|c|c|c|}
\hline \multirow{2}{*}{ Food } & \multirow{2}{*}{$\mathrm{n}^{1}$} & \multirow{2}{*}{$\mathrm{Egg}^{2}$} & \multirow{2}{*}{ Larva $^{2}$} & \multirow{2}{*}{ Protonymph $^{2}$} & \multirow{2}{*}{ Deutonymph ${ }^{2}$} & \multicolumn{2}{|c|}{ Adult } & \multirow{2}{*}{ Egg-adult $^{3}$} \\
\hline & & & & & & Female $^{3}$ & Male $^{3}$ & \\
\hline T. desertorum & 31 & $2.45 \pm 0.57 b$ & $1.16 \pm 0.37 \mathrm{a}$ & $1.42 \pm 0.50 \mathrm{a}$ & $1.35 \pm 0.49 \mathrm{a}$ & $6.37 \pm 0.99 \mathrm{~A} \mathrm{~b}$ & $6.50 \pm 0.84 \mathrm{~A} \mathrm{~b}$ & $6.39 \pm 0.95 b$ \\
\hline P. citri & 30 & $1.13 \pm 0.35 \mathrm{a}$ & $1.67 \pm 0.48 b$ & $1.43 \pm 0.50 \mathrm{a}$ & $1.33 \pm 0.48 a$ & $5.58 \pm 0.58 \mathrm{~A} \mathrm{a}$ & $5.50 \pm 0.55 \mathrm{Aa}$ & $5.57 \pm 0.57 a$ \\
\hline
\end{tabular}

${ }^{1}$ Number of individuals tested.

${ }^{2}$ Mean \pm SD in a column followed by different uppercase letters are significantly different by t-Student $(P<0.05)$.

${ }^{3}$ Mean \pm SD in the same row followed by different lowercase letters are significantly different by $\mathrm{t}-\mathrm{Student}(P<0.05)$. 
In the adult state, the females of $N$. californicus fed with $T$. desertorum (adult egg-female $=6.37$ days) took significantly longer to reach adulthood than the females fed with $P$. citri (adult female-egg $=5.58$ days), $(t=-3.22, f d=42, p<0.05)$, the same thing happening with males of $N$. californicus $(t=$ $-2.55, \mathrm{fd}=10, p<0.05$ ).

EFFECT OF TWO FOOdS (T. DESERTORUM AND P. CITRI) ON OVIPOSITION, LONGEVITY AND SURVIVAL OF ADULT FEMALES OF N. CALIFORNICUS

The effect of the diet on the duration of the phases of the adult state of $N$. californicus are given in Table 2. No significant differences were found for all these periods between the two diets: pre-oviposition period $(t=0.00, f d=59, p=0.9999)$, oviposition ( $t=-1.84, f d=53, p=0.0715)$, postoviposition $(t=0.87, f d=59, p=0.3904)$ and longevity $(t=-1.09, f d=53$, $p=0.2788)$. The number of eggs per female was significantly higher $(t=2.40, f d=59, p<0.05)$ when the females of $N$. californicus were fed $T$. desertorum. When expressing this oviposture rate as eggs/female/day, no significant differences were found $(t=-0.45, f d=59, p=0.6543)$.

Life table parameters of Neoseivlus californicus fed With Tetranychus DESERTORUM AND PANONYCHUS CITRI.

The maximum daily oviposition rate of $N$. californicus fed with $T$. desertorum was reached on the seventh day and remained at high levels until day 18 , from that day it began to decay until it reached zero on day 33. The rate of survival of $N$. californicus fed with $T$. desertorum was maximum until day 8 and then began to decrease from day 13, where it presented a $70 \%$ survival and subsequently fell to $10 \%$ on day 26 (Fig. 1A).

The maximum daily oviposition rate of $N$. californicus fed with $P$. citri was reached on the seventh day and remained at high levels until day 16 , from that day it began to decline until it reaches zero on day 30 . The rate of survival of $N$. californicus fed with $P$. citri was maximum until day 7 and after which it

TABLE 2. Durations of phases of the adult state and the oviposition rates of Neoseiulus californicus fed with Tetranychus desertorum (n $=31$ ) and Panonychus citri $(\mathrm{n}=30)$ at $29.4^{\circ} \mathrm{C}, 42.4 \% \mathrm{RH}$, and 14:10 L:D. / Duración de los períodos adultos y tasas de oviposición de Neoseiulus californicus alimentado con Tetranychus desertorum $(n=31)$ y Panonychus citri $(n=30)$ a $29,4^{\circ} \mathrm{C} ; 42,4 \% \mathrm{HR}$ y $14: 10 \mathrm{~L}: \mathrm{O}$.

\begin{tabular}{lcc}
\hline Periods & Tetranychus desertorum & \multicolumn{1}{c}{ Panonychus citri } \\
\cline { 2 - 3 } & \multicolumn{1}{c}{ Duration of the adult stages (days \pm SD) } \\
Preoviposition & $1.00 \pm 0.00 \mathrm{a}$ & $1.00 \pm 0.00 \mathrm{a}$ \\
Oviposition & $17.17 \pm 4.63 \mathrm{a}$ & $14.84 \pm 4.95 \mathrm{a}$ \\
Postoviposition & $4.37 \pm 4.80 \mathrm{a}$ & $5.23 \pm 5.06 \mathrm{a}$ \\
Longevity & $22.53 \pm 6.50 \mathrm{a}$ & $21.06 \pm 8.65 \mathrm{a}$ \\
& \multicolumn{1}{c}{ Oviposition (eggs no. \pm SD) } \\
Total egg.female ${ }^{-1}$ & $44.00 \pm 11.20 \mathrm{a}$ & $37.55 \pm 9.07 \mathrm{~b}$ \\
Egg.female $^{-1} \cdot$ day $^{-1}$ & $2.61 \pm 0.42 \mathrm{a}$ & $2.67 \pm 0.49 \mathrm{a}$ \\
\hline
\end{tabular}

Means followed by different letters within each row are significantly different according to t-Student test $(p<0.05)$.

TABLE 3. Life table parameters of Neoseiulus californicus fed with Tetranychus desertorum $(n=31)$ and Panonychus citri ( $n=30)$. $/$ Parámetros de tabla de vida de Neoseiulus californicus alimentado con Tetranychus desertorum $(n=31)$ y Panonychus citri $(n=30)$.

\begin{tabular}{ccc}
\hline \multirow{2}{*}{ Demographic parameters } & \multicolumn{2}{c}{ Food (preys) } \\
& Tetranychus desertorum & Panonychus citri \\
\hline$R_{0}$ & $31.792 \pm 8.093 \mathrm{a}$ & $27.940 \pm 8.390 \mathrm{~b}$ \\
$r_{m}$ & $0.276 \pm 0.018 \mathrm{~b}$ & $0.308 \pm 0.017 \mathrm{a}$ \\
$T$ & $12.531 \pm 0.806 \mathrm{~b}$ & $10.737 \pm 0.554 \mathrm{a}$ \\
$\lambda$ & $1.318 \pm 0.024 \mathrm{~b}$ & $1.361 \pm 0.023 \mathrm{a}$ \\
\hline
\end{tabular}

Means followed by different letters within each row are significantly different according to t-Student test $(p<0.05)$. Data are reported as the mean \pm standard deviation 
began to decrease on day 16, where it presented a $68 \%$ survival rate and decreased to $4 \%$ on day 27 (Fig. 1B).

The values of $R_{0}$ of the three species were not significantly different $(t=1.82 ;$ d.f. $=59 ; p=0.0732$ ) (Table 3$)$. The $r_{m}$ values obtained for $N$. californicus fed with $T$. desertorum were lower than the $r_{m}$ values obtained for this phytoseiid fed with
P. citri $(t=7.12 ;$ d.f. $=59 ; p<0.0001)$. The generational time was different between the two preys ( $t=10.09$; d.f. $=52 ; p<$ 0.0001). N. californicus fed with T. desertorum had the longest generational time. The finite rate of growth also differed significantly between species ( $t=-7.25 ;$ d.f. $=59 ; p<0.0001)$.

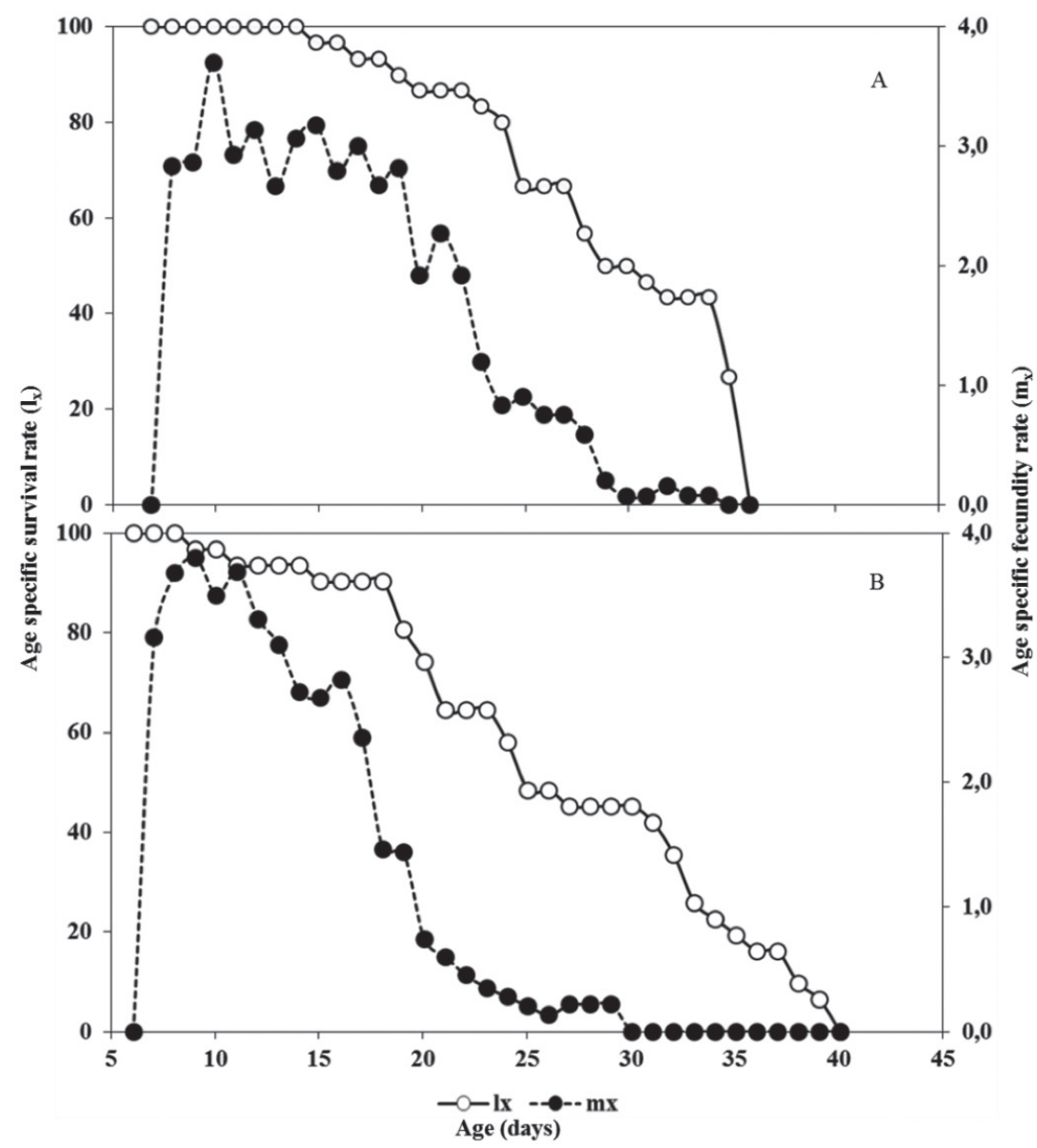

Figure 1. Age-specific survivorship $\left(\mathrm{I}_{x}\right)$ and age-specific fecundity $\left(\mathrm{m}_{x}\right)$ of Neoseiulus californicus female fed with Tetranychus desertorum (A) and Panonychus citri (B). $I_{x}=$ proportion of females alive at age $x \cdot m_{x}=$ proportion of females $x$ age-specific oviposition. / Supervivencia a una edad específica $\left(\mathrm{I}_{\mathrm{x}}\right)$ y fertilidad a una edad específica $\left(\mathrm{m}_{\mathrm{x}}\right)$ de hembras de Neoseiulus californicus alimentadas con Tetranychus desertorum (A) y Panonychus citri (B). $I_{x}=$ proporción de hembras vivas a una edad $x$. $m_{x}=$ proporción de hembras x oviposición a una edad específica.

\section{DISCUSSION}

The results obtained in the survival, and development time of $N$. californicus fed with different stages of development of $T$. desertorum and $P$. citri are congruent with those reported by Ragusa et al. (2000), who obtained $100 \%$ survival of C. picanus (=Neoseiulus idaeus Denmark \& Muma) fed with $T$. urticae eggs and $96 \%$ with P. citri, and also development times for females of $N$. picanus of 4.3 and 3.9 days, respectively, without significant differences $(p<0.05)$ between both preys. Escudero \& Ferragut (2005) obtained for T. urticae, T turkenstani Ugarov, T. ludeni Zacher and T. evansi Baker \& Pritchar: 93.2; 91.4; 97.1 and $75.7 \%$ survival, respectively. Gotoh et al. (2006) obtained a high survival of Cydnodromus (=Neoseiulus) californicus feeding it with eggs of T. urticae and T. kanzawai Kishida, therefore, they were considered of high nutritional value. Pratt et al. (1999) obtained a high percentage of survival by feeding Neoseiulus fallacis (Garman) with different stages of T. urticae (100 \%) and T. lintearius Dufour (94\%). 
The fecundity (total eggs / female) of N. californicus was affected by the diet. Ragusa et al. (2000) using T. urticae and $P$. citri to feed N. picanus, found no significant differences in the total eggs/female. These differences may be due to different species of phytoseiid or to the environmental conditions of the tests, since Ragusa et al. (2000) worked with a temperature of $26 \pm 1{ }^{\circ} \mathrm{C}$ and $70 \pm 5 \%$ of $\mathrm{RH}$. Kustutan and Çakmak (2009) recorded a fecundity of 37.18 eggs/ female for $N$. californicus fed with $T$. cinnabarinus at $30^{\circ} \mathrm{C}$, similar to our results for P. citri. Kazak et al. (2002) obtained a total fertility for Neoseilus umbricatus Chant of 43.6 eggs/ females at $30^{\circ} \mathrm{C}$, using a diet of all stages of $T$. cinnabarinus.

The larval emergence percentages for $N$. californicus obtained in this study, far exceed the reports published in the literature on the survival of eggs in low $\mathrm{RH}$ conditions. N. californicus obtained $73 \%$ of hatching at a RH close to $40 \%$. The high survival of $N$. californicus eggs can be compared with Euseius citrifolius (De Vis et al. 2006) and C. picanus $(=N$. idaeus) at similar $\mathrm{RH}$, found that E. citrifolius (Denmark \& Muma) and Metaseiulus camelliae (Chant \& Yoshida-Shaul) have a high viability in their eggs in the low humidity season, indicating that these species persist in the dry season. In the African sub-Sahara, the netropical phytoseiid Typhlodromus aripo (De Leon), is an excellent biological control of the cassava spider mite Mononychellus tanajoa (Bondar) and is able to survive the dry and hot season, at very low densities in the microenvironment of the cassava apex (Zundell et al. 2007). Neoseiulus idaeus (Denmark \& Muma) is able to survive in arid areas; the eggs of this phytoseiid are very tolerant of low humidity, supporting less than $30 \% \mathrm{RH}$; larval stages survive both the absence of food and water, and the adult stages are good controllers of Tetranychus spp. (Van Dinh et al. 1988).

According to Bakker et al. (1993), air humidity is one of the main factors that influence the efficiency of predatory mites, likewise, Sabelis (1985) and Walzer et al. (2007) indicate that the egg is the state most susceptible to adverse weather conditions. The other stages are mobile and can be moved towards favorable microenvironments to protect itself against adverse conditions. Walzer et al. (2007) breeding eight $N$. californicus strains from France, Italy, Spain, Chile and the United States at $25^{\circ} \mathrm{C}$ and four levels of relative humidity that fluctuated between 64.0 and $75.5 \%$. The most promising strains lines to act in low humidity environments, with high probability of survival of eggs and juvenile states were found in the California-United States strains and the Sicily-Italy strains. The prevalence of $N$. californicus in the desert zone of Chile may be partially explained by its capacity to tolerate conditions of high temperature and low $\mathrm{RH}$.

Tello et al. (2011), obtained for P. iorgius a Ro of 28.913 females/generation when it fed with eggs of $T$. desertorum. These results were similar to those of Abou-Setta et al. (1997) who reported rates of 23.69 for $P$. rotendus fed with $T$. urticae eggs. In our study a Ro of 31.792 females/generation was obtained. The small difference in these results may be due to experimental conditions such as temperature, relative humidity and photoperiod. Ragusa et al. (2000) obtained rates similar to those obtained in our investigation (29.94 and 28.35 females/generation for $C$. picanus fed with eggs of $T$. urticae and $P$. citri, respectively), however, the photoperiod and temperature were similar, instead the $\mathrm{RH}$ was particularly low in our assay, but affecting poorly the eggs viability. This seems to indicate that $\mathrm{N}$. californicus has a high reproductive capacity when feeding with these species of tetraniquids under these extreme experimental conditions. The Ro rates obtained in this trial for N. californicus fed with $T$. desertorum and $P$. citri describe a promising biocontroller for these phytophagous mites.

The intrinsic rate of increase indicates the multiplication capacity from one unit of time to the next (Rabinovich 1980), and indicates the potential control of a natural enemy, in time, for a given plague (Persad \& Khan, 2002; Kontodimas et al. 2007). Table 4 shows 28 studies analyzed, ordered by $r_{m}$ from highest to lowest. To establish comparisons between the studies, the data were grouped into three ranges: high, medium and low, ubicating our study of $\mathrm{N}$. californucus fed with $P$. citri in the high range, can be considered as a phytoseiid species highlighted for biological control. N. californicus fed with $T$. desertorum it ubicate in the middle range of the table.

It's possible that the good performance of $N$. californicus may be due to $P$. citri being a more nutritious prey for this phytoseido than $T$. desertorum. It could also be argued that by feeding $N$. californicus with a mixture of all stages of development of each tetraniquid, in the case of T. desertorum, for producing its females very dense webs (Piedrahita, 1974), this may have affected its performance when it fed with this tetraniquid.

Tello et al. (2009b) obtained values of $r_{m}=0.289$ for $N$. picanus fed with eggs and mixed diet of T. cinnabarinus, under experimental conditions of $29^{\circ} \mathrm{C}$ and $42 \% \mathrm{RH}$, these values are similar to those obtained in this study with respect to $\mathrm{N}$. californicus fed with $T$. desertorum where the $r_{m}=0.269$. It is necessary to indicate that there are few studies with relative humidity as low as that of our trials. 
TABLE 4. Demographic parameters for species of phytoseiids fed on eggs of different species of mites of the family Tetranychidae, at the different temperature $\left({ }^{\circ} \mathrm{C}\right)$ and relative humidity $(\% \mathrm{RH})$ conditions indicated for each species. / Parámetros de tablas de vida para distintos fitoseídos criados sobre huevos de diferentes arañitas de la familia Tetranychidae, a diferentes condiciones de temperatura $\left({ }^{\circ} \mathrm{C}\right)$ y humedad relativa (\% HR) indicadas para cada especie.

\begin{tabular}{|c|c|c|c|c|c|c|c|}
\hline Phytoseiidae & $\begin{array}{l}\text { Prey } \\
\text { (Tetranychidae species) }\end{array}$ & $r_{m}$ & $\lambda$ & $\mathrm{T}$ & Ro & $\begin{array}{c}\text { Experimental } \\
\text { conditions }{ }^{\circ} \mathrm{C} \text {, } \\
\% \mathrm{RH}\end{array}$ & References \\
\hline P. persimilis & T. Iudeni & 0.424 & - & 11.57 & 40.78 & $25,70-80$ & Escudero \& Ferragut (2005) \\
\hline P. longipes & T. evansi & 0.416 & 1.380 & 8.17 & 13.84 & $30,80 \pm 10$ & Ferrero et al. (2007) \\
\hline C. picanus & T. urticae & 0.377 & 1.458 & 9,00 & 29.9 & $26,70 \pm 5$ & Ragusa et al (2000) \\
\hline P. persimilis & T. urticae & 0.373 & - & 12.85 & 45.61 & $25,70-80$ & Escudero \& Ferragut (2005) \\
\hline P. persimilis & T. turkestani & 0.367 & - & 12.79 & 43.02 & $25,70-80$ & Escudero \& Ferragut (2005) \\
\hline C. californicus & T. urticae & 0.34 & 1.405 & 10.45 & 19.73 & $30,70-80$ & Gotoh et al. (2004) \\
\hline C. californicus & T. ludeni & 0.337 & - & 16.04 & 47.37 & $25,70-80$ & Escudero \& Ferragut (2005) \\
\hline C. californicus & T. urticae & 0.311 & 1.365 & 11.23 & 32.95 & $25,70-80$ & Gotoh et al. (2006) \\
\hline N. californicus & P. citri & 0.307 & 1.360 & 10.79 & 27.40 & 29,42 & This study \\
\hline C. californicus & T. kanzawai & 0.306 & 1.359 & 11.5 & 33.94 & $25,70-80$ & Gotoh et al. (2006) \\
\hline P. longipes & T. evansi & 0.293 & 1.230 & 12.92 & 13.88 & $25,80 \pm 10$ & Ferrero et al. (2007) \\
\hline N. californicus & P. ulmi & 0.290 & 1.340 & 11.81 & 31.88 & $30,65 \pm 75$ & El Taj \& Jung (2012) \\
\hline C. picanus & T. cinnabarinus & 0.289 & 1.335 & 11.68 & 29.13 & $29,42 \pm 5$ & Tello et al. (2009b) \\
\hline C. californicus & T. urticae & 0.285 & 1.250 & 16.79 & 16.74 & $30,70-80$ & Canlas et al. (2006) \\
\hline C. californicus & T. urticae & 0.283 & - & 17.46 & 49.25 & $25,70-80$ & Escudero \& Ferragut (2005) \\
\hline C. californicus & T. urticae & 0.274 & 1.316 & 15.303 & 28.56 & $25,70-80$ & Gotoh et al. (2004) \\
\hline P. fragariae & T. urticae & 0.273 & 1.242 & 15.60 & 29.70 & $25,88 \pm 7$ & Nascimento et al. (2008) \\
\hline N. californicus & T. desertorum & 0.269 & 1.310 & 12.85 & 31.80 & 29,42 & This study \\
\hline C. californicus & T. turkestani & 0.267 & - & 17.89 & 42.93 & $25,70-80$ & Escudero \& Ferragut (2005) \\
\hline P. iorgius & T. desertorum & 0.225 & 1.252 & 14.961 & 28.91 & $23,70 \pm 5$ & Tello et al. (2011) \\
\hline C. picanus & P. citri & 0.209 & 1.233 & 15.93 & 28.35 & $26,70-75$ & Ragusa et al. (2000) \\
\hline C. californicus & T. urtiae & 0.209 & 1.230 & 17.55 & 22.92 & $25,70-80$ & Canlas et al. (2006) \\
\hline P. macropilis & T. urticae & 0.193 & 1.213 & 18.45 & 35.34 & $26,60 \pm 10$ & Da Silva et al. (2005) \\
\hline N. umbricatus & T. cinnabarinus & 0.180 & - & 17.50 & 23.50 & $30,65 \pm 10$ & Kazak et al. (2002) \\
\hline N. idaeus & T. urticae & 0.168 & - & 10.15 & 5.53 & $25,77 \pm 2$ & Collier et al. (2007) \\
\hline P. fragariae & T. evansi & 0.123 & 1.131 & 17.4 & 8.50 & $25,88 \pm 7$ & Nascimento et al. (2008) \\
\hline I. degenerans & T. urticae & 0.115 & - & 20.2 & 10.30 & $25,75 \pm 5$ & Vantorhout (2006) \\
\hline P. persimilis & T. evansi & 0.106 & - & 14.21 & 4.37 & $25,70-80$ & Escudero \& Ferragut (2005) \\
\hline
\end{tabular}

Biological parameters, $R_{0}=$ net reproductive rate, $r_{m}=$ intrinsic rate of growth, $T=$ mean generation time, and $\lambda=$ finite rate of growth. 
According to Sabelis (1985), phytoseiid species with $\lambda>1.2$ are considered good candidates for the biological control of prolific mites. However, some species of phytoseiids, such as Typhlodromus pyri Scheuten, with low rm and $\lambda$, are considered as very important biological control agents of Panonychus ulmi (Koch) in the field (Hansen $\&$ Johnsen 1986). Our results are very similar to those obtained by Escudero \& Ferragut (2005) with N. californicus on $T$. urticae (1.33 females/day). The results obtained from $\lambda$ and $r_{m}$ can be considered positive, and it can be proposed that $N$. californicus could be an efficient biocontroller agent of red spiders of the Tetranychidae family. N. californicus generates high expectations as a biological controller in arid areas of northern Chile. N. californicus could be used in hot and dry agroecosystems where it is difficult to find phytoseeds adapted to extreme conditions for the control of tetraniquids, since the strain of N. californicus found in the Atacama Desert, would be more adapted to conditions of food shortage and aridity.

\section{REFERENCES}

Abou-Setta, M.M., Fouly, A.H., Childers, C.C. 1997. Biology of Proprioseiopsis rotendus (Acari: Phytoseiidae) reared on Tetranychus urticae (Acari: Tetranychidae) or Pollen. The Florida Entomologist 80(1): 27-34.

Ansaloni, T., Aucejo, S., Jacas, J.A. 2007. Estimating the intrinsic rate of increase of Tetranychus urticae: which is the minimum number of immature individuals to consider? Experimental and Applied Acarology 41: 55-59.

Bakker, F.M., Klein, M.E., Mesa, M.C., Braun, A.R. 1993. Saturation deficit tolerante spectra of phytophagous mites and their phytoseiid predators on cassava. Experimental and Applied Acarology 17(1-2): 97-113.

Birch, L.C. 1948. The intrinsic rate of natural increase of an insect population. Journal of Animal Ecology 17: 15-26.

Bolland, H.R., Gutiérrez, J., Fletchmann, C.H.W. 1998. World catalogue of the spider mite family (Acari: Tetranychidae): Leiden, Koninklijke Brill NV. 408 p.

Canlas, L.J., Amano, H., Ochiai, N., Takeda, M. 2006. Biology and predation of the Japanese strain of Neoseiulus californicus (McGregor) (Acari: Phytoseiidae). Systematic and Applied Acarology 11: 141-157.

Castagnoli, M., Simoni, S. 2003. Neoseiulus californicus (McGregor) (Acari: Phytoseiidae): survey of biological and behavioural traits of a versatile predator. Redia 86: 153-164.

Çobanoğlu, S., Faraji, F., Cilbircioğlu, C. 2018. Re-descriptions of Amblyseius decolor (Westerboer) and Proprioseiopsis sororculus (Wainstein) (Acari: Phytoseiidae) based on the specimens collected in Turkey and France. Acarologia 58(4): 825-836.

Collier, K., Albuquerque, G., De Lima, J., Pallini, A., MolinaRugama, A. 2007. Neoseiulus idaeus (Acari: Phytoseiidae) as a potential biocontrol agent of the two-spotted spider mite, Tetranychus urticae (Acari: Tetranychidae) in papaya: performance on different prey stage - host plant combinations. Experimental and Applied Acarology 41: 27-36.

Da Silva, F., Vasconcelos, G., Gondim, M., Oliveira, J. 2005. Exigências térmicas e tabela de vida de fertilidade de Phytoseiulus macropilis (Banks) (Acari: Phytoseiidae). Neotropical Entomology 34:291-296.

De Moraes, G.J., Mcmurtry, J.A., Denmark, H.A., Campos, C.B. 2004. A revised catalog of the mite family Phytoseiidae. Zootaxa 434: 1-494.

De Vis, R.M.J., De Moraes, G.J., Bellini, M.R. 2006. Effect of air humidity on the viability of predatory mites (Acari: Phytoseiidae, Stigmaeidae) common on rubber trees in Brazil. Experimental and Applied Acarology 38 (1): 25-32.

El Taj, H.F., Jung, C. 2012. Effect of temperature on the life-history traits of Neoseiulus californicus (Acari: Phytoseiidae) fed on Panonychus ulmi. Experimental and Applied Acarology 56(3): 247-260.

Escudero, L.A., Ferragut, F. 2005. Life-history of predatory mites Neoseiulus californicus and Phytoseiulus persimilis (Acari: Phytoseiidae) on four spider mite species as prey, with special reference to Tetranychus evansi (Acari: Tetranychidae). Biological Control 32: 378-384.

Ferrero, M., Moraes G.J., Kreiter, S., Tixier, M.-S., Knapp, M. 2007. Life tables of the predatory Phytoseiulus longipes feeding on Tetranychus evansi at four temperatures (Acari: Phytoseiidae, Tetranychidae). Exp. Appl. Acarol. 41: 45-53.

Ghazi, N.A., Osakabe, M., Negm, M.W., Schausberger, P., Gotoh, T., Amano, H. 2016. Phytoseiid mites under environmental stress. Biological Control 96: 120-134.

Gotoh, T., Yamaguchi, K., Mori, K. 2004. Effect of temperature on life history of the predatory mite Amblyseius (Neoseiulus) californicus (Acari: Phytoseiidae). Experimental and Applied Acarology 32: 15-30.

Gotoh, T., Tsuchiya, A., Kitashima, Y. 2006. Influence of prey on developmental performance, reproduction and prey consumption of Neoseiulus californicus (Acari: Phytoseiidae). Experimental and Applied Acarology 40:189-204.

Hansen, E.W., Johnsen, S. 1986. Predatory mites of the family Phytoseiidae in Denmark (Acarina, Gamasina). Entomologiske Meddelelser 53(3): 137-142.

Kazak, C., Yildiz, S., Sekeroglu, E. 2002. Biological characteristic 
and life tables of Neoseiulus umbricatus Chant (Acari: Phytoseiidae) at three constant temperatures. J. Pest Science, 75: 118-121.

Kim, T., Ahn, J.J., Lee, J.-H. 2012. Age- and temperaturedependent oviposition model of Neoseiulus californicus (McGregor) (Acari: Phytoseiidae) with Tetranychus urticae as prey. Journal of Applied Entomology 137(4): 282-288.

Klein, C., Waterhouse, D.F. 2000. Distribution and importance of arthropods associated with agriculture and forestry in Chile. ACIAR Monograph N 68. 231 pp.

Kontodimas, D.C., Milonas, P.G, Stathas, G.J., Economou, L.P., Kavallieratos, N.G. 2007. Life table parameters of the pseudococcid predators Nephus includens and Nephus bisignatus (Coleoptera: Coccinellidae). European Journal of. Entomology 104: 407-415.

Kuştutan, O., Çakmak, I. 2009. Development, fecundity, and prey consumption of Neoseiulus californicus (McGregor) fed Tetranychus cinnabarinus Boisduval. Turkish Journal of Agriculture and Forestry 33: 19-28.

Mirabal, L. 2003. Los ácaros depredadores como agentes de control biológico. Revista de Protección Vegetal 18(3): 145-152.

Muma, M.H. 1971. Food habits of phytoseiidae (Acarina: Mesostigmata) including common species on Florida citrus. The Florida Entomologist 54(1): 21-34.

Nascimento, G., Moraes, G.J., Delalibera, I., Knapp, M. 2008. Life history of the predatory mite Phytoseiulus fragariae on Tetranychus evansi and Tetranychus urticae (Acari: Phytoseiidae, Tetranychidae) at five temperatures. Experimental and Applied Acarology 44: 27-36.

Nunes-Maia, A., Almeida-Pazianotto, R., Barreto-Luiz, A., Marinho-Prado, J., Pervez, A. 2014. Inference on arthropod demographic parameters: Computational advances using R. Journal of Economic Entomology 107(1): 432-439.

Peralta, O., Tello, V. 2019. Phytoseiid mites (Acari: Phytoseiidae) from the Region of Tarapacá, northern Chile, with a description of a new species and a key to species. International Journal of Acarology 45(3): 148-158.

Persad, A., Khan, A. 2002. Comparison of life table parameters for Maconellicoccus hirsutus, Anagyrus kamali, Cryptolaemus montrouzieri and Scymnus coccivora. Biocontrol 47: 137149.

Piedrahita, J. 1974. Biologia de Tetranychus desertorum Banks (Acarina, Tetranychidae) y pruebas de resistencia de siete variedades de frijol (Phaseolus vulgaris) a su ataque. Acta Agronómica 24(1-4): 94-114.

Pratt, P.D., Schausberger, P., Croft, B.A. 1999. Prey-food types of Neoseiulus fallacies (Acari: Phytoseiidae) and literatura versus experimentally derived prey-food estimates for five phytoseiid species. Experimental and Applied
Acarology 23: 551-565.

R Core Team. 2018. R: A language and environment for statistical computing. R Foundation for Statistical Computing, Vienna, Austria. URL: https://www.R-project.org/.

Rabinovich, J.E. 1980. Introducción a la ecología de poblaciones animales. CECSA. 313 pp.

Ragusa, S. 2000. A new Cydnodromus (Parasitiform, Phytoseiidae), from the desert of the northern Chile. Phytophaga 10: 3-103.

Ragusa, S. 2003. Description of a new genus and two new species of phytoseiid mites (Parasitiformes Phytoseiidae) collected in Chile. Acarologia 43:337-344.

Ragusa, S., Vargas, R. 2002. On some phytoseiid mites (Parasitiformes, Phytoseiidae) from Chile. Phytophaga 12: 129-139.

Ragusa, S., Vargas, R., Tsolakis, H., Ashbach, R. 2000. Laboratory studies on the influence of various food subtances on some biological and life-table parameters of Cydnodromus picanus Ragusa (Parasitiformes, Phytoseiidae) associated with citrus trees in the Chilean desert. Phytophaga 10: 11-23.

Sabelis, M.W., 1985. Predation on spider mites. En: Helle, W., Sabelis, M.W. (Eds) Spider Mites, Their Biology, Natural Enemies and Control: 103-127. World Crop Pests, Vol. 1B. Elsevier, Amsterdam.

Shen, X.M., Liao, C.Y., Lu, X.P., Wang, Z., Wang, J.J., Dou, W. 2016. Involvement of three esterase genes from Panonychus citri (McGregor) in fenpropathrin resistance. International Journal of Molecular Science 17(8): 1361. doi: 10.3390/ ijms17081361.

Swirski, E., Amitai, S., Dorzia, N. 1970. Laboratory studies of the feeding habits, post-embryonic survival, and oviposition of the predaceous mites Amblyseius chilenensis Dosse and Amblyseius hibisci Chant (Acariña: Phytoseudae) on various kinds of food substances. Entomophaga 15: 93106.

Tello, V., Briceño, V., Castillo, P. 2011. Parámetros biológicos de Proprioseiopsis iorgius sobre Tetranychus desertorum (Acari: Phytoseiidae, Tetranychidae). Revista Colombiana de Entomología 37(1): 62-66.

Tello, V., Castillo, P., Briceño, R., Sánchez, M. 2013. Parámetros biológicos de Tetranychus desertorum (Acari:Tetranychidae) sobre hojas de poroto. IDESIA 31(4): 27-33.

Tello, V., Vargas, R., Araya, J. 2009a. Parámetros de vida de Tetranychus cinnabarinus (Acari: Tetrachychidae) sobre hojas de clavel, Dianthus caryophyllus. Revista Colombiana de Entomología 35(1): 47-51.

Tello, V., Vargas, R., Araya, J., Cardemil, A. 2009b. Biological parameters of Cydnodromus picanus and Phytoseiulus persimilis raised on the carmine spider mite, Tetranychus 
cinnabarinus (Acari: Phytoseiidae, Tetranychidae). Ciencia e Investigación Agraria 36(2): 277-290.

Vantornhout, I. 2006. Biology and ecology of the predatory mite Iphiseius degenerans (Berlese) (Acari: Phytoseiidae). PhD thesis, Ghent University, Ghent, Belgium.

Van Dinh N., Sabelis M.W., Janssen, J. 1988. Influence of Humidity and Water Availability on the Survival of Amblyseius idaeus and $A$. anonymus (Acarina: Phytoseiidae). Experimental and Applied Acarology 4: 27-40.

Vargas, R., Olivares, N., Cardemil, A. 2005. Desarrollo postembrionario y parámetros de tabla de vida de Typhlodromus pyri Scheuten, Cydnodromus californicus (McGregor) (Acarina: Phytoseiidae) y Brevipalpus.
Agricultura Técnica (Chile) 65(2): 147-156.

Walzer, A., Castagnoli, M., Simoni, S., Liguori, M., Palevsky, E., Schausberger, P. 2007. Intraspecific variation in humidity susceptibility of the predatory mite Neoseiulus californicus: Survival, development and reproduction. Biological Control 41: 42-52.

Zar, J.H. 2010. Biostatistical Analysis. 5th Edition, Prentice-Hall/ Pearson, Upper Saddle River. 944 p.

Zundell, C.H., Hanna, R., Scheidegger, U., Nagel, P. 2007. Living at the threshold: Where does the neotropical phytoseiid mite Typhlodromus aripo survive the dry season? Experimental and Applied Acarology 41(1-2): 11-26.

Received: 22.09 .2019

Accepted: 24.04.2020 